\title{
Contents of Journals Relating to Work
}

Technology and Disability, Vol. 4, Nos. 3, 4; 1995

Assistive technology and persons with developmental disabilities

Editorial

Introduction

The use of assistive technology by people with mental retardation and barriers to this outcome: A pilot study

M.L. Wehmeyer (USA)

Assistive technology for cognitive disability

M. Granlund, A. Bond, E. Lindstrom, B. Wennberg (Sweden)

Augmentive and alternative communication (ACC) assessment and prescriptive practices for young

children with disabilities: Preliminary examination of state practices

H.P. Parette (USA)

Project FACTT: meeting the communication needs of children with severe developmental disabilities

R.A. Sevcik, M.A. Romski, V. Collier, C. Rayfield, B. Nelson, A. Walton-Bowe, D. Jordan

M. Howell, J. Ross (USA)

Persons with disabilities and jobs - a problem unresolved

J.H. Leslie (USA)

Job accommodations for persons with disabilities: Can they be reasonable?

L. Anderson (USA)

The transition from nursing homes to community living for people with developmental disabilities:

An assessment of the assistive technology needs and usage

L.S. Mendelson, T. Heller, A.R. Factor (USA)

Wheelchair seating intervention for a person with developmental disabilities living in a skilled nursing facility: The 'Bogard' consent decree

J. Presperin Pedersen (USA)

The use of mobility related devices by older individuals with developmental disabilities living in community residences

M.A.F. de Mello, W.C. Mann (Brazil, USA)

Case study - adapting a TV/VCR control for a person with severe developmental disability

B.F. Willems, D. Loebl (USA)

Custom device development and professional training in developmental disabilities

W.C. Mann, S.M. Nochajski, S.H. Sprigle, B.M. Riordan (USA)

Calendar 
Journal of Vocational Rehabilitation, Vol. 6, No. 1, 1996

International Symposium on Supported Employment

Editorial

Introduction

Using person-centered planning concepts to enhance school-to-adult life transition planning J.M. Everson (USA)

Including people with disabilities in community recreation activities

M.S. Moon (USA)

Consumer choice and satisfaction in supported employment

W. Parent (USA)

Stress and burnout: how to manage your time and avoid stress as an employment specialist

G. Sasnett, C. Wesley (USA)

Parents in charge of the system: strategies for increasing supported employment opportunities for individuals with severe disabilities

S.G. Killam, I. Petranek, G. Harding (USA)

Parents' perspectives on current and future community services and supports

A. Comegys, R. Ainsworth (USA)

Mentors in self-advocacy: beacons to employment

E. Turner, E. Perry-Varner (USA)

Customer driven approach to organizational change

A. Bodgan (USA)

Organizational evolution: critical pathways to substantive change

C.C. Griffin (USA)

Building relationships with employers by applying solid customer service principles

G. Tilson, Jr. (USA)

Evolving roles for employers and support personnel in the employment of people with severe disabilities

D.M. Mank (USA)

Local beginnings - global impact: the OPEN ROAD project

C.S. Lynch, P.N. Walsh (Ireland)

Supported employment behind the Netherland's dikes: Trends in vocational rehabilitation for persons with psychiatric disabilities

M.H.T. Korpel (The Netherlands)

The Pachysandra Project: A public - private initiative in supported employment at the Prudential Insurance Company of America

M.M. Miano, E.B. Nalven, D. Hoff (USA) 